\title{
BIOLOGICAL CONTROL OF SOME PIERCING-SUCKING INSECT PESTS OF THE BEAN (PHASEOLUS VULGARIS L.) UNDER OPEN FIELD AND GREENHOUSE CONDITIONS
}

\author{
M. O. Kolaib ${ }^{(1)}$, M. E. Sweelam ${ }^{(1)}$, M. B. Attia ${ }^{(1)}$, Violette S. Gurguis ${ }^{(2)}$ \\ and Wedyan F. El-Madboh ${ }^{(2)}$ \\ (1) Faculty of Agric. Menoufia Univ., Shebin Elkom, Egypt. \\ (2) Plant Res. Protection Institute, Agricultural Res. Center, Giza, Egypt.
}

Received: Sep. 19, 2016

Accepted: Sep. 24, 2016

\begin{abstract}
This work was conducted to study the biological impact of releasing the elevenspotted ladybeetle, Coccinella undecimpunctata, Linnaeus (Coleoptera: Coccinellidae) in the control of the cotton whitefly, Bemisia tabaci , Gennadius, the cotton aphid, Aphis gosspyii , Glover infesting common bean, Phaseolus vulgaris, Linnaeus. Experiments were carried out during the period of 15 February, till 15 May 2014 at a private farm and a greenhouse located at El-Menoufia Governorate, Egypt. Biweekly leaf samples were examined for the different stages of insects under study to determine the efficacy and the optimum time for releasing the predator. The obtained results indicated that the highest reduction percentages of preys (83.1\%) at the level of 15 larvae/ plant under greenhouse conditions, were recorded four weeks after releasing. The grand mean reduction percentages of aphid and whitefly stages under greenhouse conditions along ten weeks of releasing were 38.24, 45.86, and $49.68 \%$ for the treatments of 5, 10 and 15 newly hatched larvae/plant, respectively. Under open field conditions, the results revealed that the highest reduction percentages of preys were recorded at the eighth and tenth week after releasing. The grand mean reduction percentages of aphid and whitefly stages under open field conditions along ten weeks of releasing were 38.0, 39.9, and $40.9 \%$ for the treatments of 5, 10 and 15 freshly hatched larvae/plant, respectively.
\end{abstract}

Key words: Biological control, bean (Phaseolus vulgaris), Coccinella undecimpunctata, Aphis gossypii, Bemisia tabaci.

\section{INTRODUCTION}

In Sub-Saharan Africa (SSA) the conventional agrosystems are minimal, due to the high costs which make the farmers unable to do this. (Neuenschwander, 2004). As well as, pesticides using have unintended effects on environment. As an example, over $98 \%$ of sprayed insecticides reach the station other than their target species including non-target species, air, water, and food (Miller, 2004). The best solution to control unneeded organisms use biological control with natural enemies (van Lenteren and Woets, 1988, Herren and Neuenschwander, 1991). Coccinellids are important to biological control more often than any other predatory organisms (Hodek and Honek, 2009; Jervis and Kidd, 1996). Coccinellids are important natural enemies of pest species, especially whiteflies (Gerling, 1990), aphids (Frazer, 1988), mealy bugs (Hagen, 1974), scale insects (Drea and Gordon, 1990), and mites (Chazeau, 1985). Over 50 species of Coccinellidae attack eggs and immature stages of whitefly (Gerling, 1990) of which, 13 species prey on Bemisia species (Nordlund and Legaspi, 1996 and Gerling 1986), whereas 40 species prey on $A$. disperses (Ramani, 2000). For instance, Serangium parcesetosum feeds on various whitefly species on citrus (Uygun et al., 1997), and Clitostethus arcuatus is a predator of several whitefly species in various crops (Booth and Polaszek, 1996). Serangium spp. were found to prey on whiteflies in cassava throughout the growing period (Asiimwe et al., 2007). Additionally, 
Coccinellids such as Anegleis cardoni, A. perrotteti, Axinoscymnus puttarudriahi, Chelomenes sexmaculata, three species of Jauravia and Cryptolaemus montrouzieri were found heavily feeding on the spiraling whitefly (Mani and Krishnamoorthy, 1997).

People in the food industry and governments around the world have come to conceive the vital need for green houses to supplement food supplies. Over population in the world need more greenhouses to provide more food.

Egypt has about 3000 feddan greenhouses divers between greenhouses and tunnels. Vegetables are the main crops grown in these greenhouses such as pepper, tomatoes, cucumber, squash and beans which are infested with a lot of pests.

Piercing-sucking pests are of the important pests which infest plants and need to wreck completely. The way of feeding causes damage by their stylet-like mouthparts through plant tissue directly. The most important enemies of piercing-sucking pests were coccinellids which control several pests. (Brown, 2004).

Most species of ladybirds are considered beneficial because they are predators of Homoptera or Acarina, some are considered pest species. These predatory ladybirds contribute to the regulation of populations of their prey, and in some situations contribute a high level of regulation. During The $20^{\text {th }}$ century, Coccinellid species have spread in North America including Coccinella undecimpunctata (Gorden\&Vandenberg 1991; Hoebeke \& Wheeler 1996 and Atuncha et al., 2013). Biological control with using predators against insect pests was successively applied under field conditions or in greenhouse shields (Simmons and Abd- Rabou 2011).

This article was conducted to evaluate the possibility of using Coccinella undecimpunctata in the control of some piercing sucking insects infesting common bean, Phaseolus vulgaris under shield and field conditions.

\section{MATERIALS AND METHODS Rearing of Coccinella undecimpunctata: \\ Prey culture:}

Broad bean, Vicia faba plants naturally infested with the aphid species, Aphis gossypii or with the whitefly Bemisia tabaci were collected from the field, transferred to the laboratory and re-cultivated in $20 \mathrm{~cm}$ plastic pots filled with clay loam soil to be a continuous source of aphids and whitefly as preys for the predator culture and release experiments.

\section{Predator culture:}

Adult individuals of $\boldsymbol{C}$. undecimpunctata were collected from vegetable crops at Shebin Elkom, Menoufia Governorate, Egypt. Collected predator adults were placed in a plastic tube contains moistened cotton pads and transferred to the laboratory. Under laboratory conditions, trapped predators were placed in plastic containers $(40 \times 40 \times 40 \mathrm{~cm})$ each contain about 500 individuals provided with fresh aphids infested broad bean leaves to feed on. Pieces of white paper $200 \mathrm{~g}(4 \times 4 \mathrm{~cm})$ were placed in the container for predators to lay egg on. The paper sheets with the eggs were collected and placed in Petri dishes for experimental applications under laboratory conditions (Zhang and Feng, 1983 \& Jin et al., 2010).

\section{Greenhouse site:}

A private greenhouse $(25 \times 8 \mathrm{~m})$, located at Shebin Elkom, Menoufia Governorate, was cultivated by the common bean (Phaseolus vulgaris L.), var. Bronco. Seeds were planted at rows with $50 \mathrm{~cm}$ distance between rows and $20 \mathrm{~cm}$ between holes. The area was divided into 12 plots each was $(4 \times 4 \mathrm{~m})$. There was a free row as border between plots to prevent treatment contamination. 


\section{Field site :}

In a private farm located at Shebin ElKom, Menoufia Governorate an area of $25 x$ $8 \mathrm{~m}$ (about $200 \mathrm{~m}^{2}$ ) of land was also cultivated by the common bean ( $P$. vulgaris ), var. Bronco, in rows with $50 \mathrm{~cm}$ distance between rows and $20 \mathrm{~cm}$ between holes. This area was divided into 12 plots each plot was $(4 \times 4 \mathrm{~m})$. There was a free row as border between plots to prevent treatment contamination.

\section{Releasing process:}

All treatments of both shield and field experiments were arranged in a complete randomized block design. Each treatment was applied at 3 plots as three replicates.

Thirty days of seed cultivation, grown plants were manually infested with 100 aphid and 100 white fly stages /plant, at both shield and field plots.

Seven days later, the predator was released at the levels of 5, 10 and 15 newly hatched larvae / plant, (about 100 plant per replicate ) while control plots were left without release process. Plants were sprayed with $1 \%$ sugar solution at sunset, using a hand sprayer, to prevent, escaping of predators. The average means of air temperature degree and relative humidity was about $25 \pm 7^{\circ} \mathrm{C}$ and $60 \pm 10$ R.H $\%$ in field and $25 \pm 2^{\circ} \mathrm{C}$ and $65 \pm 5$ R.H $\%$ in shield plots.

Weekly counts of both prey and predator individuals were done per 5 leaves / replicate for 10 weeks at the laboratory with the aid of dissecting stereomicroscope. Investigations were done for 3 replicates per each treatment.

\section{Statistical analysis:}

Obtained data was statistically analyzed using analysis of variance (ANOVA) at $5 \%$ probability. The measurements were separated using Duncan's Multiple Range Test (DMRT) through CoStat software program (Version 6.400) 1998-2008. Reduction percentages were calculated according to Henderson and Tilton (1955).

\section{RESULTS AND DISSCUTION Greenhouse experiments:}

Data presented in Table (1) indicated that releasing $C$. undecimpunctata under greenhouse conditions reduced the average numbers of aphid and whitefly stages infesting common bean leaves. Statistical analysis of data revealed that there were significant differences in the numbers of preys between control and all other treatments, while there were insignificant differences among the three levels of release.

As for reduction percentages, results in Table (1) indicated that the highest reduction percentages of preys were recorded four weeks after releasing. The grand mean reduction percentages of aphid and whitefly stages along ten weeks of releasing were $38.24,45.86$, and $49.68 \%$ for the treatments of $5,10,15$ newly hatched larvae/plant, respectively.

\section{Open field experiments}

Data presented in Table (2) indicated that releasing $\mathrm{C}$. undecimpunctata under open field conditions reduced the average numbers of aphid and whitefly stages infesting common bean leaves. Statistical analysis of data revealed that there were significant differences in the numbers of preys between control and all other treatments, as well as there were significant differences in the observed numbers of preys among the three levels of release.

As for reduction percentages, results in Table (2) indicated that the highest reduction percentages of preys were recorded in the $8^{\text {th }}$ and $10^{\text {th }}$ weeks after releasing at all evaluated levels of predator. The grand mean reduction percentages of aphid and whitefly stages along ten weeks of releasing were $38.0,39.9$, and $40.9 \%$ for the treatments of $5,10,15$ newly hatched larvae/plant, respectively. 
Kolaib, et al.,

Table (1): Average numbers of aphid and whitefly stages attacking bean plants post releasing $C$. undecimpunctata and the reduction percentages, under greenhouse conditions

\begin{tabular}{|c|c|c|c|c|c|c|c|}
\hline \multirow{3}{*}{$\begin{array}{l}\text { Release } \\
\text { level }\end{array}$} & \multicolumn{6}{|c|}{$\begin{array}{c}\text { Ave. no of aphid \& whitefly stages /5 leaves } \\
\text { (Reduction percentages) }\end{array}$} & \multirow{3}{*}{$\begin{array}{l}\text { The grand } \\
\text { mean } \\
\text { reduction\% }\end{array}$} \\
\hline & \multicolumn{6}{|c|}{ Period post release (weeks) } & \\
\hline & $\begin{array}{l}\text { Pre- } \\
\text { release }\end{array}$ & 2 & 4 & 6 & 8 & 10 & \\
\hline $\begin{array}{l}5 \text { larvae } \\
\text { /plant }\end{array}$ & $42 \mathrm{a}$ & $\begin{array}{c}35 \mathrm{a} \\
(12.3)\end{array}$ & $\begin{array}{c}8 \mathrm{~b} \\
(80.7)\end{array}$ & $\begin{array}{c}11 \mathrm{~b} \\
(10.3) \\
\end{array}$ & $\begin{array}{c}6 \mathrm{~b} \\
(55.7)\end{array}$ & $\begin{array}{c}4 \mathrm{~b} \\
(42.2)\end{array}$ & (38.24) \\
\hline $\begin{array}{l}10 \text { larvae/ } \\
\text { plant }\end{array}$ & $36 \mathrm{~b}$ & $\begin{array}{l}25 \mathrm{~b} \\
(26.9)\end{array}$ & $\begin{array}{c}6 \mathrm{~b} \\
(79.7)\end{array}$ & $\begin{array}{l}9 \mathrm{~b} \\
(2.2)\end{array}$ & $\begin{array}{c}4 \mathrm{~b} \\
(63.9)\end{array}$ & $\begin{array}{c}2 \mathrm{~b} \\
(56.6)\end{array}$ & $(45.86)$ \\
\hline $\begin{array}{c}15 \text { larvae/ } \\
\text { plant }\end{array}$ & $39 \mathrm{ab}$ & $\begin{array}{c}15 \mathrm{c} \\
(59.5)\end{array}$ & $\begin{array}{c}3 \mathrm{~b} \\
(83.1)\end{array}$ & $\begin{array}{l}5 \mathrm{~b} \\
(8.7) \\
\end{array}$ & $\begin{array}{c}2 \mathrm{~b} \\
(67.5)\end{array}$ & $\begin{array}{c}2 \mathrm{~b} \\
(29.6)\end{array}$ & (49.68) \\
\hline Control & $40 \mathrm{ab}$ & $38 a$ & $45 a$ & $69 a$ & $85 a$ & 98 a & - \\
\hline LSD $5 \%$ & 3.8 & 5.5 & 4.9 & 6.1 & 4.7 & 3.8 & \\
\hline
\end{tabular}

Means in each column followed by the same letter are not significantly different at $5 \%$ level.

Table (2): Average numbers of aphid and whitefly stages attacking bean plants post releasing $C$. undecimpunctata under open field conditions

\begin{tabular}{|c|c|c|c|c|c|c|c|}
\hline \multirow{2}{*}{$\begin{array}{c}\text { Release } \\
\text { level }\end{array}$} & \multicolumn{6}{|c|}{ Ave. no of aphid \& whitefly /5 leaves } & \multirow{2}{*}{\begin{tabular}{c} 
The grand \\
mean \\
\cline { 2 - 7 }
\end{tabular}} \\
\cline { 2 - 7 } & $\begin{array}{c}\text { Pre- } \\
\text { releasing }\end{array}$ & 2 & 4 & 6 & 8 & 10 & \\
\hline 5 larvae/ plant & $65 \mathrm{a}$ & $\begin{array}{c}52 \mathrm{a} \\
(2.9)\end{array}$ & $\begin{array}{c}37 \mathrm{~b} \\
(45.4)\end{array}$ & $\begin{array}{c}27 \mathrm{~b} \\
(35.0)\end{array}$ & $\begin{array}{c}14 \mathrm{~b} \\
(54.8)\end{array}$ & $\begin{array}{c}12 \mathrm{~b} \\
(52.0)\end{array}$ & $(38.0)$ \\
\hline 10 larvae/ plant & $44 \mathrm{~b}$ & $\begin{array}{c}39 \mathrm{~b} \\
(6.7)\end{array}$ & $\begin{array}{c}30 \mathrm{c} \\
(40.9)\end{array}$ & $\begin{array}{c}20 \mathrm{~b} \\
(40.7)\end{array}$ & $\begin{array}{c}12 \mathrm{~b} \\
(47.7)\end{array}$ & $\begin{array}{c}8 \mathrm{c} \\
(62.7)\end{array}$ & $(39.9)$ \\
\hline 15 larvae/ plant & $48 \mathrm{~b}$ & $\begin{array}{c}23 \mathrm{c} \\
(17.2)\end{array}$ & $\begin{array}{c}16 \mathrm{~d} \\
(46.6)\end{array}$ & $\begin{array}{c}13 \mathrm{c} \\
(27.7)\end{array}$ & $\begin{array}{c}6 \mathrm{~b} \\
(59.7)\end{array}$ & $\begin{array}{c}5 \mathrm{~d} \\
(53.4)\end{array}$ & $(40.9)$ \\
\hline Control & $68 \mathrm{~b}$ & $56 \mathrm{a}$ & $73 \mathrm{a}$ & $82 \mathrm{a}$ & $94 \mathrm{a}$ & $168 \mathrm{a}$ & - \\
\hline LSD 5\% & 6.6 & 5.2 & 5.9 & 12.5 & 13.5 & 2.8 & \\
\hline
\end{tabular}

Means in each column followed by the same letter are not significantly different at $5 \%$ level.

Obtained results, indicated that the release process was more effective in reducing aphid and whitefly numbers in greenhouses than those under open field conditions; this may be due to the relatively controlled conditions inside the greenhouses.

These results are in agreement with Bratu (1998) who determined the efficiency of the predator C. septempunctata L. released in the egg stage to reduce populations of the pest Myzus persicae (Sulz.) in pepper crops, El-Habi et al.(1999) controlled $A$. gossypii on cucumber under glass by $C$. septempunctata. Also, the obtained results are in harmony with those obtained in Egypt by Zaki et al. (1999) ; AlEryan et al. (2001) who used C. 11punctata (Coleoptera: Coccinellidae) against A. gossypii . on okra plant; Halima (2005) stated a program for the biological control of A. gossypii on pepper plant using Coccinella algerica. Abd-Rabou (2008) studied mass production, releasing and evaluation of $C$. undecimpunctata for controlling of aphids in Egypt. In addition, Obrycki et al. (2009) reported that coccinellids and aphids interact in a wide range of agricultural and forest habitats and the value of coccinellid 
predation for aphid suppression in these systems varied from a minor role to significant reductions leading to withinseason control. Furthermore, Hodek and Honek (2009) stated a review survey of food relationships of coccidophagous, aleurodophagous and psyllophagous coccinellids, and found that while in cold temperate climate aphids are the dominant prey group (68\% of ladybird species), globally, coccids are the dominant prey group of $(36 \%)$ of coccinellid species, and only $(20 \%)$ prey primarily on aphids. Special attention was given to the physiological and environmental factors that affect the nutritive suitability of prey. Recently in Egypt Simmons and Abd-Rabou (2011) reported that The use of predators as a biological control method against many insect pests was successively applied under field conditions or in greenhouse shields (Simmons and Abd-Rabou 2011).

From the obtained results, it could be concluded that the releasing process significantly controlled aphid and whitefly insects and could be successively applied in greenhouses at the rate of 10 larvae of lady bird predator at a threshold of 100 insect stages of aphids or /and white fly per plant.

\section{REFERENCES}

Abd-Rabou, S. (2008). Mass production, releasing and evaluation of the lady beetle, Coccinella undecimpunctata (Coleoptera: Coccinellidae), for control of aphids in Egypt. Archives of Phytopathology and Plant Protection; 41(3):187-197.

Al-Eryan, M. A. S., A. A. Zaitoon and H. A. Rezk (2001). The use of Coccinella 11punctata (Coleoptera: Coccinellidae) against Aphis gossypii (Homoptera: Aphididae) on okra plant. Alexandria Journal of Agricultural Research; 46(1):107-114.

Atuncha, H., E. Ateka R. Amata, R. Mwirichia, M. Kasina, B. Mbevi and E. Wakoli (2013). Evaluation of predation potential of coccinellids on cassava whiteflies. Journal of Entomology and Nematology, 5(7) 84-87.

Asiimwe, P., J.S. Ecaat, M. Guershon, S. Kyamanywa, D. Gerling and J.P. Legg (2007). Evaluation of Serangium n. sp. (Col., Coccinellidae), a predator of Bemisia tabaci (Hom., Aleyrodidae) on cassava. J. Appl. Entomol. 131:76-80.

Booth, R.G. and A. Polaszek (1996). The identities of ladybird beetle predators used for whitefly control, with note on some whitefly parasitoids, in Europe. Brighton Crop Protection Conference, Pests and Diseases. British Crop Protection Council, Thornton Heath, UK, pp.69-74.

Bratu, E. (1998). Efficiency of the predator Coccinella septempunctata $\mathrm{L}$. (Coleoptera: Coccinellidae) released in the egg stage to reduce populations of the pest Myzus persicae (Sulz.) In pepper crops. Anale Institutul de Cercetari pentru Legumicultura si Floricultura, Vidra; 15:215-229.

Brown, M. N. (2004). Role of aphid predator guild in controlling spirea aphid populations on apple in West Virginia, USA. Biological Control 29:189 - 198.

Chazeau, J. (1985). Predaceous insects. In: Spider Mites, Their Biology, Natural Enemies and Control. Ed. by Sabelis W, New York, Elsevier, pp. 211-244.

CoStat version 6.400 Copyright (C) 19982008 Cohort Software. 798 Lighthouse Ave. PMB 320, Monterey, CA, 93940, USA.

Drea, J. and D.Gordon (1990). Coccinellidae. In Armored Scale Insects: Their Biology, Natural Enemies, and Control. Ed. by Rosen D. pp.19-40.

Gordon, R.D. and N. Vandenberg (1991). Field guide to recently introduced species of Coccinellidae (Coleoptera) in North America, with a revised key to North American genera of Coccinelle. Proceedings Entomological Society Washington 93:845 - 964.

Frazer, B. (1988). Coccinellidae. In Aphids: Their Biology, Natural Enemies and Control, Ed. Minks K, Harrewijn P, York; Amsterdam: Elsevier. pp. 231-247.

El-Habi, M., L. El-Jadd, A. Sekkat and A. Boumezzough (1999). Control of Aphis 
Kolaib, et al.,

gossypii (Glover.) (Homoptera: Aphididae) on cucumber under glass by Coccinella septempunctata Linnaeus (Coleoptera: Coccinellidae).Insect Science and its Application; 19(1):57-63.

Gerling, D. (1986). Natural enemies of Bemisia tabaci, biological characteristics and potential as biological control agents: a review. Agric.Ecosyst.environ.17:99110.

Gerling, D. (1990). Natural enemies of whiteflies: predators and parasitoids. In Whiteflies: Their Bionomics, Pest Status and Management, ed. by Gerling D, Andover: Intercept Ltd, pp.147-185.

Hagen, K.S. (1974). The significance of predaceous Coccinellidae in biological and integrated control of insects. Entomophaga 7, 25-44.

Halima-Kamel, M. B. (2005). Biological control of Aphis gossypii on pepper plant using Coccinella algerica. Communications in Agricultural and Applied Biological Sciences; 70(4):737743.

Henderson, C.F. and E. W. Tilton (1955). Tests with acaricides against the brow wheat mite, J. Econ. Entomol. 48:157-161.

Herren, R. and P. Neuenschwander (1991). Biological control of cassava pests in Africa. Annu. Rev. Entomol. 36:257-283.

Hoebeke, E.R. and A.G. Wheeler (1996). Adventive lady beetles (Coleoptera: Coccinellidae) in the Canadian maritime provinces, with new eastern US records of Harmonia quadripunctata. Entomol. News 107:281 - 290.

Hodek, I. and A. Honek (2009). Scale insects, mealy bugs, whiteflies and psyllids (Hemiptera, Sternorrhyncha) as prey of ladybirds. Biological Control 51 (2): 232-243.

Jervis, M. and N. Kidd (1996). Insect Natural Enemies: Practical Approaches to Their Study and Evaluation. New York: Chapman \& Hall, pp.491.

Jin, J. X., C. Ying, L. F. Liang, L. Z. Ying and C. X. Sheng (2010). Study on rearing method of Coccinella septempunctata fed by Aphis craccivora. Guizhou Agricultural Sciences; (4):121-124.

Mani, M. and A. Krishnamoorthy (1997). Discovery of Australian ladybird beetle
(Cryptolaemus montrouzieri) on spiraling whitefly (Aleurodicus dispersus) in India. Insect Env; 3:5-6.

Miller, G.T. (2004). Sustaining the Earth In: Thompson Learning. Ed. 6. by Inc, Pacific Grove, California. pp. 211-216.

Neuenschwander, P. (2004). Harnessing nature in Africa: Biological pest control can benefit the pocket, health and the environment. Nature, 432:801-802.

Nordlund, D. A. and J. C. Legaspi (1996). Whitefly predators and their potential for use in biological control. 71:499-513.

Obrycki, John, J. D. Harwood, T. J. Kring and R. J. O'Neil (2009). Aphidophagy by Coccinellidae: Application of biological control in agroecosystems Coccinellids and aphids interact in a wide range of agricultural and forest habitats and the value of Coccinellidae. Biological Control, $51(2): 244-254$.

Ramani, S. (2000). Fortuitous introduction of an aphelinidae parasitoid of the spiralling whitefly, Aleurodicus dispersus Russell (Homoptera: Aleyrodidae), into the Lakshadweep Islands with notes on host plants and other natural enemies. J. Biol. Control. 14:55-60.

Simmons, A. M. and S. Abd-Rabou (2011). Inundative field releases and evaluation of three predators for Bemisia tabaci (Hemiptera: Aleyrodidae) management in three vegetable crops. Insect Science; 18(2):195-202.

Uygun, N., M. Ulusoy, Y. Karaca and U. Kersting (1997). Approaches to biological control of Dialeurodes citri (Asmead) in turkey. Bull.IOBCWPRS.2052-56.

Van Lenteren, J. C. and J. Woets (1988). Biological and integrated control in greenhouses. Annu. Rev. Entomol. 33: 239- 269.

Zaki, F. N., M. F. El-Shaarawy and N. A. Farag (1999). Release of two predators and two parasitoids to control aphids and whiteflies. Anzeiger fur Schadlingskunde; 72(1):19-20.

Zhang, Y. J. and Y. S. Feng (1983). Smallscale rearing of Coccinella septempunctata L. (Coleoptera: Coccinellidae) and the efficacy of field releases. Natural Enemies of Insects (Kunchong Tiandi); 5(2):97-99. 


\section{المكافحة البيولوجية للحشرات الثاقبة الماصة التى تصيب الفاصوليا تحت ظروف الحقل والصوية}

محمد على عمر كليب(1) ، محمد الامين سويلم(1) ، مكرم باسيلى عطيه(1) ،

فيوليث شكرى جرجس (2) ، وديان فتحى مصيلحى(2)

(1) قسم الحشرات الاقتصادية والحيوان الزراعى - كلية الزراعة - جامعة المنوفية - مصر.

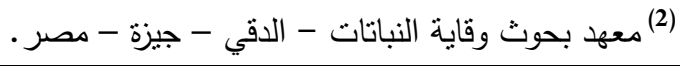

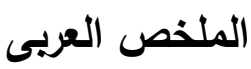

تم اجراء هذا البحث تحت الظروف المعليـة وتحت الظروف الحقلية بمزرعة وصوبة خاصـة بمركز شبين الكوم، محافظة المنوفية ، مصر ، وذللك فى الفترة من منتصف فبراير وحتى منتصف مايو للعام 2014 ، لمكافحة

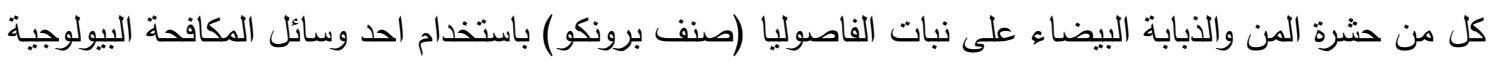
وهى اطلاق مفترس ابى العيد ذى الاحدى عشرة نقطة تحت ظروف ونس الحقل والصوبة.

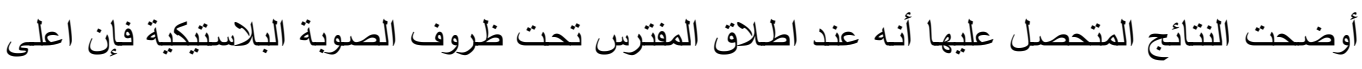

منوسط عام لنسبة موت للفرائس (المن والذبابة البيضاء) كانت 49,68 ٪ عند اطلاق 15 يرقة حديثة الخروج

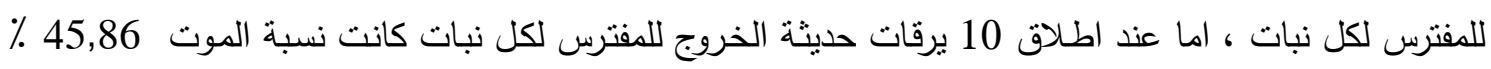

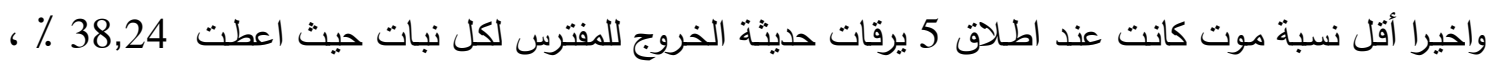

وسجلت اعلى نسبة موت للفرائس بعد 4 اسابيع من الاطلاق (83,1\% ) عند مستوى اطلاق 15 يرقة /نبات .

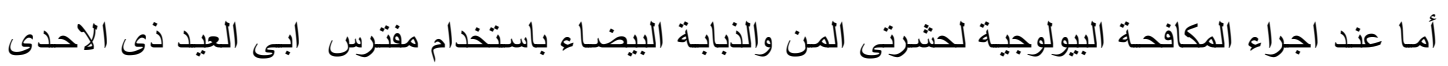
عشرة نقطة تحت ظروف الحقل المفتوح ، سجلت النتائج أن أعلى نسبة موت للفرائس (المن والذبابة البيضـاء) كانت 40,9 ٪ عند اطلاق 15 يرقة حديثة الخروج للمفترس لكل نبات ، وعند اطلاق 10 يرقات حديثة الخروج

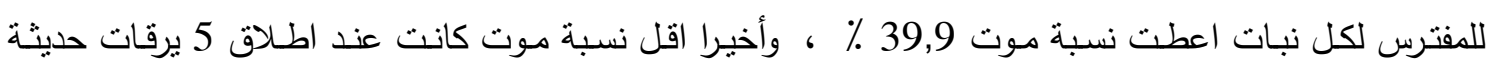
الخروج للمفترس لكل نبات وأعطت 38 ٪ ، ويوصى البحث بإمكانية استخدام المفترس بنجاح ضد الحشرات الثاقبة الماصة فى كل من الحقل المفتوح والصوب وان كان الاطلاق فى الصوب اعطى نتائج عالية. 